\title{
Okazja jako wyznacznik przedsiębiorstwa zwinnego - studium przypadku
}

\author{
Dr inż. Paweł Królas iD \\ Politechnika Poznańska \\ Wydział Inżynierii Zarządzania
}

\section{Wprowadzenie}

Zmiany zachodzące w otoczeniu przedsiębiorstwa znacząco wpływają na organizacje. Ich dynamika nasiliła się w ciągu ostatniej dekady. Dotyczy to zarówno zmian technologicznych zachodzących w gospodarce, postępującej automatyzacji i robotyzacji przedsiębiorstw, jak i wzrostu znaczenia proekologicznych rozwiązań.

Zmiany zachodzące w otoczeniu mogą oddziaływać na organizacje w sposób pozytywny, negatywny i neutralny. Nieprzewidywalność negatywnego i neutralnego otoczenia stanowi dla organizacji źródło potencjalnego zagrożenia. Zmiany pozytywne mogą być traktowane jako szanse lub okazje dla przedsiębiorstwa. Różnica między nimi sprowadza się do wystąpienia elementu prawdopodobieństwa związanego z czasem, kompletnością zasobów i celem działania, co jest utożsamiane z szansą. Sytuacja sprzyjająca dla podmiotu działania jest charakterystyczna dla okazji ${ }^{1}$. Literatura przed miotu szeroko opisuje zagadnienia dotyczące zmienności otoczenia ${ }^{2}$. Znane są również pozycje, które przedstawiają zagadnienie przedsiębiorstwa zwinnego ${ }^{3}$. Pozycje te ukazują przedsiębiorstwo zwinne w odniesieniu do: marketingu, zasobów ludzkich, zarządzania wiedzą, zarządzania

1 S. Trzcieliński, Zwinne przedsiębiorstwo, Wydawnictwo Politechniki Poznańskiej, Poznań 2011.

2 I. Ansof, Zarzqdzanie strategiczne, Państwowe Wydawnictwo Ekonomiczne, Warszawa 1985; P.F. Drucker, Myśli przewodnie Druckera, Wydawnictwo MT Biznes, Warszawa 2001; W.M. Grudzewski i wsp., Sustainability w biznesie. Przedsiębiorstwo przyszłości, Wydawnictwo Poltext, Warszawa 2010.

3 S. Trzcieliński, Zwinne...; L. Holbeche, The agile organization, Kogan Page, London 2015; J. Rothman, Agile and Lean, Practical Ink, Arlington 2016; F. Olajiga, Lean agile marketing. How to become agile and deliver marketing success, Conversion Ltd., Northampton 2017; H. Włodarkiewicz-Klimek, Kapitat ludzki w kształtowaniu zwinności przedsiębiorstw opartych na wiedzy, Wydawnictwo Politechnik Poznańskiej, Poznań 2018; M. Sajdak, Zwinność 
procesami, wystąpienia okazji czy też zarządzania strategicznego, a także innych obszarów. W piśmiennictwie ciągle niewiele pozycji opisuje podział okazji i ich wpływ na sukces przedsiębiorstwa.

Za cel główny opracowania przyjęto określenie wpływu wykorzystania okazji na powodzenie przedsiębiorstwa. Kontekst celu głównego obejmuje dwa obszary. Pierwszy dotyczy przedsiębiorstwa zwinnego i jego znaczenia dla organizacji. Drugi jest związany z wystąpieniem okazji i jej istotnością dla przedsiębiorstwa zwinnego.

W części teoretycznej rozdziału zaprezentowano idee przedsiębiorstwa zwinnego i jego znaczenie dla organizacji. W części empirycznej przedstawiono wyniki badań, które zostały przeprowadzone na grupie dziesięciu celowo wybranych MSP, znajdujących się w województwie wielkopolskim, małopolskim i pomorskim. Badania zostały przeprowadzone w latach 2014-2018.

\section{Przedsiębiorstwo zwinne i jego istota}

Początki przedsiębiorstwa zwinnego są związane z publikacją Iacocca Institute $\mathrm{z}$ Lehigh Univeristy w USA pt. Raport 21st Century manufacturing enterprise: An industry led view z 1991 roku. Główne założenia zwinności w przedstawionym raporcie dotyczyły nowego sposobu wytwarzania dla amerykańskiego przemysłu, tak aby zapewnić przywództwo i konkurencyjność. Było to związane ze zmierzchem ery masowej produkcji i koniecznością otworzenia się na nowe idee. W takich warunkach przez zwinność rozumiano umiejętność rozwoju w środowisku nieprzewidywalnym i ciągłych zmian przy jednoczesnej poprawie konkurencyjności. Było to możliwe dzięki ${ }^{4}$ :

- tworzeniu interdyscyplinarnych zespołów projektowych;

- cyklowi życia produktu;

- dostępności wiedzy naukowej oraz zastosowaniu dedykowanych komputerów w procesie wytwarzania;

- modułowości, elastyczności, rekonfiguracji oraz adaptacji procesów produkcyjnych;

- możliwości uzyskania właściwych informacji i optymalnego transferu wiedzy;

- modułowemu projektowaniu produktów, rekonfiguracji i rozbudowie, które sprzyjały maksymalnemu wydłużaniu cyklu życia produktu.

strategiczna przedsiębiorstw, Wydawnictwo Uniwersytetu Ekonomicznego w Poznaniu, Poznań 2019 i inni.

4 H. Włodarkiewicz-Klimek, Kapitat ludzki... 
W roku 1995 Goldman, Nagel i Preiss ${ }^{5}$ określi zwinność jako zdolność do odnoszenia sukcesów w konkurencyjnym otoczeniu, w którym powstają okazje dzięki nieprzewidywalnym zmianom zachodzącym na rynku. Z kolei Yusuf, Sarhadi i Gunasekaran ${ }^{6}$ przez zwinność rozumieją skuteczny sposób diagnozowania podstaw konkurencji (szybkości, elastyczności, proaktywności, innowacyjności, jakości i rentowności) poprzez integrację, rekonfigurację zasobów oraz najlepsze praktyki w otoczeniu bogatym w wiedzę, w celu zapewnienia produktów i usług tworzonych z udziałem klienta w zmieniającym się otoczeniu. Lu i Ramamurthy ${ }^{7}$ uważają, że zwinność można określić w dwóch wymiarach: rynkowej i operacyjnej kapitalizacji zwinności. W pierwszym przypadku zwinność dotyczy zarządzania wiedzą i zdolnością intelektualną. Jest to związane z gromadzeniem i przetwarzaniem dużej ilości różnorodnych informacji służących do identyfikacji i przewidywania zmian zewnętrznych oraz z ciągłym monitorowaniem i szybkim doskonaleniem produktów/usług w celu zaspokojenia potrzeb klienta. W drugim przypadku zwinność jest związana z szybką reakcją na zmiany popytu poprzez zamiany w wewnętrznych procesach biznesowych organizacji. Z kolei Doz i Kosonen ${ }^{8}$ przez zwinność rozumieją zdolność przedsiębiorstwa do myślenia i działania w sposób odmienny niż inni, prowadzący do opracowania nowych, innowacyjnych modeli biznesowych. Według Trzcielińskiego ${ }^{9}$ przedsiębiorstwo zwinne ma zdolność do wykorzystania okazji występujących w otoczeniu przedsiębiorstwa. Tym samym do wymiarów zwinności należy zaliczyć ${ }^{10}$ :

- bystrość - umiejętność dostrzegania zdarzeń zachodzących w otoczeniu i kategoryzowanie ich jako sytuacje sprzyjające lub niesprzyjające dla organizacji;

- elastyczność - umiejętność oceny adekwatności zasobów (własnych i cudzych) niezbędnych do wykorzystania okazji;

- inteligencję - umiejętność wartościowania sytuacji sprzyjającej przy racjonalnym wykorzystaniu zasobów;

- spryt - umiejętność rozwiązywania problemów związanych z wykorzystaniem okazji na poziomie operacyjnym, w tym rekonfigurowanie dostępnych

5 S. Goldman, R. Nagel, K. Preiss, Agile competitors and virtual organization. Strategies for enriching the customer, Van Nostrand Reinhold, New York 1995, s. 8, 42-43.

6 Y.Y. Yusuf, M. Sarhadi, A. Gunasekaran, Agile manufacturing: the drivers, concepts and attributes, „International Journal of Production Economics” 1999, vol. 62(1-2), s. 33-43.

7 Y. Lu, K. Ramamurthy, Understanding the link between information technology capability and organizational agility: an empirical examination, „MIS Quarterly” 2011, vol. 35(4), s. 931.

8 Y.L. Doz, M. Kosonen, Fast strategy. How strategic agility will help you stay ahead of the game, Wharton School Publishing, London 2008.

9 S. Trzcieliński, Zwinne...

10 Tamże. 
zasobów, inicjowanie i modyfikowanie niezbędnych przedsięwzięć i bieżącego ich sterowania.

Według Banaszaka ${ }^{11}$ zwinne przedsiębiorstwo wspiera się na kilku kluczowych filarach, a mianowicie: jest bliskie rynku i klienta finalnego, cechuje się strategicznym przywództwem, ma elastyczny potencjał operacyjny, sprawnie współpracuje $z$ dostawcami oraz wykorzystuje informatyczne systemy wspierające zarządzanie. Według Aghiny, De Smeta i Weerdy ${ }^{12}$ zwinne przedsiębiorstwa powinny być zarówno stabilne (odporne, niezawodne i wydajne), jak i dynamiczne (szybkie, zwrotne i adaptacyjne). Taki pogląd podzielają również Brosseau i współautorzy ${ }^{13}$, którzy uważają, że zwinne przedsiębiorstwo potrafi w sposób idealny połączyć prędkość i zdolność adaptacji ze stabilnością i wydajnością. Punktem centralnym takiego rozumienia zwinności jest strategia (rysunek 1).

Przedstawiony model dotyczy przede wszystkim dużych przedsiębiorstw czy też korporacji. Jednak niektóre elementy przedstawionego modelu w części lub w całości mogą być zastosowywane w małych i średnich przedsiębiorstwach (MSP).

Z kolei Sajdak ${ }^{14}$ rozpatruje zwinność przedsiębiorstwa poprzez:

- zwinność wytwarzania - rozumianą jako umiejętność przetrwania i radzenia sobie w konkurencyjnym otoczeniu, pełnym nieprzewidywalnych zmian, wymagających szybkiej i skutecznej reakcji15;

- zwinność organizacyjną - dotyczącą aspektów organizacji procesów i zasobów, którymi dysponuje przedsiębiorstwo w taki sposób, aby mogło uzyskać i utrzymać przewagę konkurencyjną w turbulentnym otoczeniu;

- zwinność strategiczną - rozumianą jako zdolność do podejmowania zmian strategicznych i radzenia sobie z dynamiką (zmiennością) otoczenia; zdolność tę konstytuują cztery atrybuty: wrażliwość strategiczna, przedsiębiorczość strategiczna, elastyczność oraz przywództwo strategiczne ${ }^{16}$.

11 P. Banaszak, Zwinne dostosowanie przedsiębiorstw na rynkach z okazjonalna przewaga konkurencyjnq, „Ruch Prawniczy, Ekonomiczny i Socjologiczny” 2014, z. 1, s. 185-210.

12 W. Aghina, A. De Smet, K. Weerda, Agility: It rhymes with stability, „McKinsey Quarterly”, December 2015, s. 1-12.

13 D. Brosseau, S. Ebrahim, C. Handscomb, S. Thaker, The journey to an agile organization, „McKinsey Quarterly”, May 2019, s. 1-10.

14 M. Sajdak, Zwinność strategiczna...

15 A. Gunasekaran, Agile manufacturing: A framework for research and development, „International Journal of Production Economics" 1999, vol. 62(1-2), s. 87.

16 M. Sajdak, Zwinność strategiczna... 


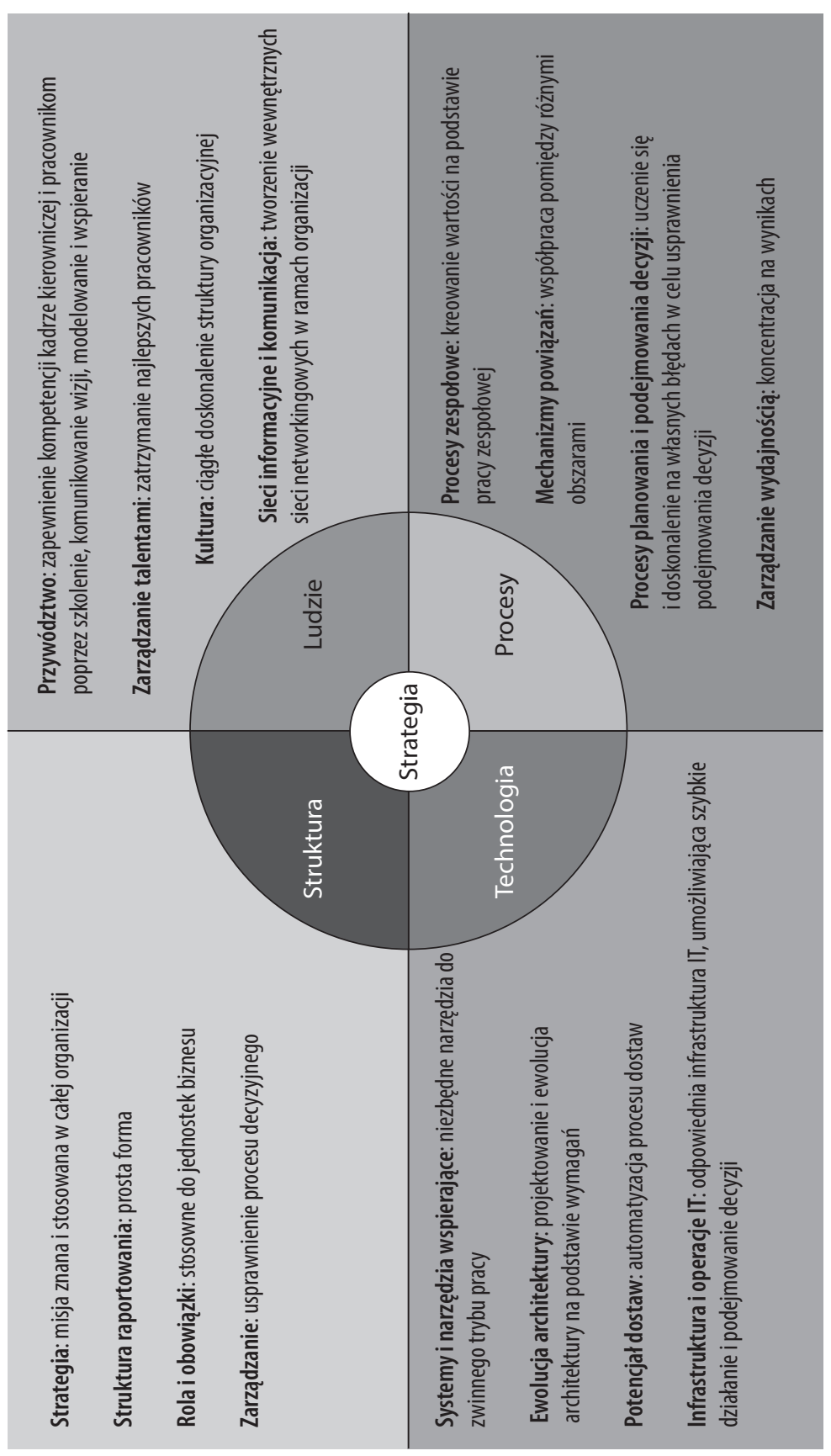


Pomimo pewnych różnic w przedstawionych definicjach i podejściach można wyróżnić wspólne atrybuty zwinności, które znajdują zastosowanie zarówno w dużych przedsiębiorstwach, jak i w MSP17:

- szybkość;

- elastyczność;

- zdolność do wykorzystywania okazji;

- zdolność do rekonfigurowania zasobów wewnętrznych;

- zarządzanie wiedzą i informacją;

- odpowiedzialność wobec środowiska;

- zaspokajanie potrzeb klienta;

- jakość.

Trudno jednoznacznie wskazać, które organizacje funkcjonujące na rynku są zwinne, gdyż jest to wypadkową wielu zmiennych. Zdecydowanie łatwiej interpretować zwinność poprzez reakcje organizacji na sytuacje zachodzące w otoczeniu przedsiębiorstwa. Te sytuacje mogą stanowić okazje dla organizacji.

\section{Okazja i jej znaczenie}

Shane ${ }^{18}$ uważa, że wykorzystanie okazji może być związane z elementem zaskoczenia. Według Alvareza i Barneya ${ }^{19}$ okazje mogą istnieć niezależnie od działań i percepcji przedsiębiorstwa. Organizacje mogą kreować okazję przez działanie, łącznie różnych zasobów, improwizację, dokonywanie zmian bez dużego zaangażowania w proces poszukiwań okazji ${ }^{20}$. Hang, Garnsey i Ruan ${ }^{21}$ zauważają, że okazje są odkrywane, a także kreowane przez przedsiębiorstwa. Ardichvili, Cardozo i Ray ${ }^{22}$ sugerują, że okazje mogą być w pewnym stopniu rozpoznane, jednak zasadniczo są one kształtowane w toku celowych działań organizacji, a nie

17 H. Włodarkiewicz-Klimek, Kapitat ludzki...

18 S. Shane, Prior Knowledge and the Discovery of Entrepreneurial Opportunities, „Organization Science" 2000, vol. 11, s. 448-469.

19 S.A. Alvarez, J.B. Barney, Discovery and Creation: Alternative Theories of Entrepreneurial Action, „Strategic Entrepreneurship Journal” 2007, vol. 1, no. 1-2, s. 11-26.

20 I. Peiris, M. Akoorie, P. Sinha, Conceptualizing the Process of Opportunity Identification in International Entrepreneurship Research, „South Asian Journal of Management”, July - September 2013, vol. 20, issue 3, s. 49-50.

21 C. Hang, E. Garnsey, Y. Ruan, Opportunity Discovery and Creation in Disruptive Innovation, Centre for Technology Management Working Paper Series, Institute for Manufacturing, at the University of Cambridge, Engineering Department, no. 03, Cambridge 2003, s. 6.

22 A. Ardichvili, R. Cardozo, S. Ray, A theory of entrepreneurial opportunity identification and development, „Journal of Business Venturing” 2003, no. 18, s. 106. 
są odkrywane. Krupski ${ }^{23}$ zauważa, że okazje pojawiają się, trwają jakiś czas i znikają. Według Trzcielińskiego ${ }^{24}$ okazje są związane z domeną działania przedsiębiorstwa i utożsamiane:

- ze zdarzeniami, które występują w otoczeniu przedsiębiorstwa;

- z celem lub skutkiem działania przedsiębiorstwa;

- z potencjałem, którym dysponuje przedsiębiorstwo bądź może dysponować, a który jest konieczny do podjęcia działania, a tym samym do osiągnięcia celu.

Samo pojęcie okazja występuje zarówno w literaturze polskiej, jak i zagranicznej. W tabeli 1 przedstawiono wybrane definicje okazji.

Tabela 1. Wybrane definicje okazji

\begin{tabular}{|l|l|}
\hline \multicolumn{1}{|c|}{$\begin{array}{c}\text { Źródło } \\
\text { definicji }\end{array}$} & \multicolumn{1}{c|}{ Definicja okazji } \\
\hline Greena & $\begin{array}{l}\text { Odnosi się do potencjalnego tworzenia nowego przedsięwzięcia. Dotyczy } \\
\text { to zarówno dziatalności biznesowej, jak i non-profit, przedsięwzięcia, które } \\
\text { dostarczają wartości zarówno dla klientów, jak i właścicieli organizacji. }\end{array}$ \\
\hline Hunterb & $\begin{array}{l}\text { Jest związana z indywidualnym postrzeganiem rzeczywistości, umiejętnością } \\
\text { dostrzeżenia sprzyjających warunków, które, przez zastosowanie określonych } \\
\text { koncepcji, mogą być przestawione w postaci idei. }\end{array}$ \\
\hline Trzcielińskic & $\begin{array}{l}\text { To sytuacja sprzyjająca podmiotowi działania w osiągnięciu zamierzonego } \\
\text { celu lub pożądanego skutku, która istnieje w otoczeniu tego podmiotu lub jest } \\
\text { postulowanym stanem cech tego otoczenia. }\end{array}$ \\
\hline Sulld & $\begin{array}{l}\text { Wynika z nowej kombinacji innowacyjnych zasobów, uwzględniając } \\
\text { również technologie, procesy, tańcuch dostaw, model biznesu, utrzymując } \\
\text { lub zakłócając obecny stan poprzez rozszerzenie praktyk i/lub „zerwanie } \\
\text { z przeszłością”, tak by zaspokoić nowe potrzeby klientów. }\end{array}$ \\
\hline $\begin{array}{l}\text { Alvarez } \\
\text { i Barneye }\end{array}$ & $\begin{array}{l}\text { Zjawisko tworzone przez egzogenne wstrząsy dla istniejących gatęzi przemystu, } \\
\text { odbierane subiektywnie bądź obiektywnie przez przedsiębiorstwa. }\end{array}$ \\
\hline Krupskif & $\begin{array}{l}\text { To zdarzenie (np. upadek konkurenta) lub powstały splot różnych okoliczności } \\
\text { (np. utworzenie się niszy rynkowej) o charakterze gospodarczym (lub o skutkach } \\
\text { gospodarczych), stwarzające możliwości osiągnięcia dodatkowych korzyści, } \\
\text { wartości materialnych i/lub niematerialnych. }\end{array}$ \\
\hline $\begin{array}{l}\text { Ardichvili, } \\
\text { Cardozo } \\
\text { i Rayg }\end{array}$ & $\begin{array}{l}\text { Jest możliwością poznania potrzeb rynku przez twórcze połączenie zasobów } \\
\text { w celu osiągnięcia wyższych wartości. }\end{array}$ \\
\hline $\begin{array}{l}\text { Eckhardt, } \\
\text { Shaneh }\end{array}$ & $\begin{array}{l}\text { Jest sytuacją, w której nowe produkty, usługi, materiały, rynki i metody } \\
\text { organizacji mogą być wdrożone poprzez formutowanie nowych dla nich } \\
\text { znaczeń. }\end{array}$ \\
\hline
\end{tabular}

23 R. Krupski (red.), Elastyczność organizacji, Wydawnictwo Uniwersytetu Ekonomicznego we Wrocławiu, Wroctaw 2008, s. 49-50.

24 S. Trzcieliński, Zwinne..., s. 43. 
Tabela 1 (cd.)

\begin{tabular}{|l|l|}
\hline \multicolumn{1}{|c|}{$\begin{array}{c}\text { Źródło } \\
\text { definicji }\end{array}$} & \multicolumn{1}{c|}{ Definicja okazji } \\
\hline Koen i wsp.i & $\begin{array}{l}\text { Stanowi wolną przestrzeń (lukę) biznesową i/lub technologiczną między obecną } \\
\text { sytuacją a wizją przyszłości, rozpoznaną przez przedsiębiorstwo bądź jednostkę. } \\
\text { Dzięki wykorzystaniu przewagi konkurencyjnej można zniwelować zagrożenia } \\
\text { i rozwiązać problem. }\end{array}$ \\
\hline $\begin{array}{l}\text { Timmons, } \\
\text { Spinellij }\end{array}$ & $\begin{array}{l}\text { Jest atrakcyjna, trwata i okresowa. Jest zakorzeniona w wyrobie lub ustudze, } \\
\text { które tworzą wartość lub wartość dodaną dla nabywcy bądź ostatniego } \\
\text { użytkownika. Okazje powstają w zmiennych okolicznościach, chaosie lub } \\
\text { w warunkach braku konsekwencji, tj. w sytuacjach, w których jedni dostrzegają } \\
\text { korzyść, a inni jej nie dostrzegają, lub zbyt późno to robią. }\end{array}$ \\
\hline
\end{tabular}

a J. Green, The Opportunity Analysis Canvas. A New Tool for Identifying and Analyzing Entrepreneurial Ideas, Venture Artisans, LLC, Upper Marlboro 2015, s. 1. b M. Hunter, Typologies and sources of entrepreneurial opportunity, „Economics, Management, and Financial Markets” 2013, vol. 8(3), s. 58-59. c S. Trzcieliński, Zwinne przedsiębiorstwo, Wydawnictwo Politechniki Poznańskiej, Poznań 2011, s. 49. d D. Sull, The upside of turbulence. Seizing opportunity in an uncertain world, Harper Collins Publishers, New York 2009, s. 20-21. e S.A. Alvarez, J.B. Barney, Discovery and Creation: Alternative Theories of Entrepreneurial Action, „Strategic Entrepreneurship Journal” 2007, vol. 1, no. 1-2, s. 11-26. ${ }^{\mathrm{f}}$ R. Krupski (red.), Zarzqdzanie przedsiębiorstwem w turbulentnym otoczeniu, Polskie Wydawnictwo Ekonomiczne, Warszawa 2005, s. 49. $\mathrm{g}$ A. Ardichvili, R. Cardozo, S. Ray, A theory of entrepreneurial opportunity identification and development, „Journal of Business Venturing” 2003, no. 18, s. 105-123. h J. Eckhardt, S. Shane, Opportunities and entrepreneurship, „Journal of Management” 2003, vol. 29, s. 336. ' P. Koen i wsp., Providing clarity and a common language to the fuzzy front end, „Research Technology Management” 2001, vol. 44, s. 46-55. j J. Timmons, S. Spinelli, New ventures creation, McGraw-Hill Companies, Inc., New York 1990, s. 100-117.

Źródto: opracowanie własne.

Przedstawione definicje w różnym stopniu pokazują możliwość odniesienia korzyści przez organizacje ${ }^{25}$. Samo wystąpienie okazji jest obiektywne, jednak już jej „uchwycenie” i wykorzystanie ma charakter subiektywny. Subiektywność okazji zależy od miejsca jej wystąpienia. Okazje pojawiające się wewnątrz organizacji mają wysoki poziom subiektywności, w otoczeniu konkurencyjnym umiarkowany, a w makrootoczeniu niski (rysunek 2).

Karpacz $^{26}$ twierdzi, że w makrootoczeniu występuje niski poziom subiektywności dostrzeganych okazji. Dłuższy czas trwania okazji stwarza możliwość jej wykorzystania przez większą liczbę graczy. Taką okazję cechuje bardzo niski poziom subiektywności. Krótszy czas trwania okazji umożliwia jej wykorzystanie przez nieliczne przedsiębiorstwa. Tym samym możliwość urzeczywistnienia okazji zależy od subiektywnej oceny organizacji (wysoki poziom subiektywności) ${ }^{27}$.

25 P. Królas, Identyfikacja ryzyka zwiq̨zanego z krótkim cyklem życia okazji - studium przypadku, „Zeszyty Naukowe Politechniki Poznańskiej. Organizacja i Zarządzanie” 2019, z. 80, s. 149-163.

26 J. Karpacz, Determinanty dostrzegania i wykorzystania okazji przez przedsiębiorców, [w:] A. Stabryła (red.), Koncepcja zarzq̨dzania współczesnym przedsiębiorstwem, seria „Encyklopedia Zarządzania", Mfiles.pl, Kraków 2010, s. 47.

27 P. Królas, Identyfikacja ryzyka... 


\begin{tabular}{l|l|l}
\multicolumn{2}{c}{$\begin{array}{l}\text { Niski poziom } \\
\text { subiektywności } \\
\text { dostrzeganych okazji }\end{array}$} & Strefa makrootoczenia \\
\cline { 2 - 2 } $\begin{array}{l}\text { Wysoki poziom subiektywności } \\
\text { dostrzeganych okazji }\end{array}$ & $\begin{array}{l}\text { Strefa otoczenia } \\
\text { konkurencyjnego }\end{array}$ \\
\cline { 2 - 2 } wysoki poziom & $\begin{array}{l}\text { Strefa wewnętrzna } \\
\text { przedsiębiorstwa }\end{array}$ \\
\cline { 2 - 2 }
\end{tabular}

Rysunek 2. Poziom subiektywności postrzegania okazji

Źródło: J. Karpacz, Determinanty dostrzegania i wykorzystania okazji przez przedsiębiorców, [w:] A. Stabryła (red.), Koncepcja zarzadzania współczesnym przedsiębiorstwem, seria „Encyklopedia Zarządzania”, Mfiles.pl, Kraków 2010, s. 47.

Skat-Rørdam ${ }^{28}$ uważa, że poza otoczeniem bliższym i dalszym do źródeł wystąpienia okazji należy również zaliczyć wnętrze organizacji - wykorzystanie własnych zasobów. W tym ujęciu źródła okazji dotyczą kwestii ograniczenia kosztów związanych z prowadzeniem działalności gospodarczej na przykład poprzez zastosowanie koncepcji lean management. Autor ten twierdzi, że innym sposobem różnicowania okazji jest odniesienie do przestrzeni okazji ${ }^{29}$ (rysunek 3).



Rysunek 3. Przestrzeń okazji

Źródło: P. Skat-Rørdam, Zmiany decyzji strategicznych. Wykorzystanie okazji rynkowych do rozwoju przedsiębiorstwa, Wydawnictwo Naukowe PWN, Warszawa 2001, s. 150.

28 P. Skat-Rørdam, Zmiany decyzji strategicznych. Wykorzystanie okazji rynkowych do rozwoju przedsiębiorstwa, Wydawnictwo Naukowe PWN, Warszawa 2001, s. 149.

29 Tamże, s. 150. 
Skat-Rørdam rozróżnia okazje o charakterze taktycznym i strategicznym ${ }^{30}$. Okazje o znaczeniu strategicznym są związane z radykalną zmianą sposobu, w jakim przedsiębiorstwo bierze udział w grze konkurencyjnej. Może to również zapewnić znaczącą część obrotów przedsiębiorstwa w perspektywie długofalowej. Pozostałe zidentyfikowane okazje mają znaczenie taktyczne.

Okazje można również kategoryzować, biorąc pod uwagę poziomy zarządzania w organizacji, szczególnie z perspektywy szczebla hierarchii i niezbędnych zasobów koniecznych do wykorzystania okazji. Tym samym, w zależności od poziomu zarządzania, można wyróżnić trzy rodzaje okazji31:

- okazje o charakterze strategicznym - są związane ze znaczącą zmianą funkcjonowania przedsiębiorstwa; w ujęciu rynkowym wykorzystanie okazji oznacza umocnienie pozycji przedsiębiorstwa na rynku świadczonych usług, zapewnienie szybszego wzrostu przedsiębiorstwa niż przeciętny w branży, wzmocnienie reputacji organizacji wobec klientów, diametralną poprawę technologii wytwarzanych produktów/usług ${ }^{32}$; w ujęciu finansowym oznacza to osiągnięcie wyższych przychodów/zysków, jak również niższych kosztów całkowitych, poprawę płynności finansowej; w praktyce może to dotyczyć: akwizycji przedsiębiorstwa, dywersyfikacji działalności, wejścia na nowe rynki; stanowi to jakościowy skok w dotychczasowej działalności; okazje o charakterze strategicznym występują bardzo rzadko; wykorzystanie okazji jest związane ze znajomością rynku i preferencji klientów, jak również szerokim kapitałem relacyjnym menedżerów organizacji; horyzont czasowy, którego dotyczy ten charakter okazji, obejmuje od kilku do kilkunastu lat; okazja o charakterze finansowym wymaga dużych nakładów finansowych, a ich zwrot jest rozłożony w czasie; w przypadku niepowodzenia przedsięwzięcia wystąpić mogą duże trudności z zapewnieniem ciągłości działania;

- okazje o charakterze taktycznym - dotyczą realizacji przedsięwzięć, które wynikają z dekompozycji celów strategicznych na plany przedmiotowe $^{33}$; urzeczywistnienie okazji o charakterze taktycznym jest związane $\mathrm{z}$ inwestycją $\mathrm{w}$ innowacyjną technologię, zawiązaniem nowego partnerstwa; skutki związane z wykorzystaniem okazji mają zazwyczaj krótki horyzont czasowy - od roku do trzech lat; okazje o charakterze taktycznym

30 Tamże.

31 P. Królas, H. Włodarkiewicz-Klimek, Okazje - źródła, rodzaje i ryzyko, [w:] S. Trzcieliński, T. Zaborowski (red.), Ksztattowanie zwinności przedsiębiorstw, Komitet Nauk Organizacji i Zarządzania Polskiej Akademii Nauk, Oddział w Poznaniu, Instytut Badań i Ekspertyz Naukowych, Gorzów Wielkopolski 2015, s. 94-105.

32 A. Thomson, A. Strickland, Strategic Management. Concepts and Cases, Irwin, Burr Ridge 1993, s. 5.

33 J. Kałkowska i wsp., Zarzq̨dzanie strategiczne. Metody analizy strategicznej z przykładami, Wydawnictwo Politechniki Poznańskiej, Poznań 2010, s. 12. 
występują okresowo, są możliwe do przewidzenia; zasoby niezbędne do wykorzystania okazji o charakterze taktycznym są relatywnie mniejsze niż w przypadku okazji o charakterze strategicznym;

- okazje o charakterze operacyjnym - dotyczą realizacji przedsięwzięć, które mają wpływ na bieżącą działalność operacyjną organizacji; liczba dostępnych okazji o charakterze operacyjnym jest relatywnie duża; zasoby konieczne do wykorzystania okazji o charakterze operacyjnym są stosunkowo niewielkie; w dużym stopniu dotyczą czasu i niezbędnej organizacji zasobów na przygotowanie i wykorzystanie okazji.

Zależności zachodzące pomiędzy poszczególnymi rodzajami okazji (strategicznym, taktycznym, operacyjnym) przedstawiono na rysunku 4.

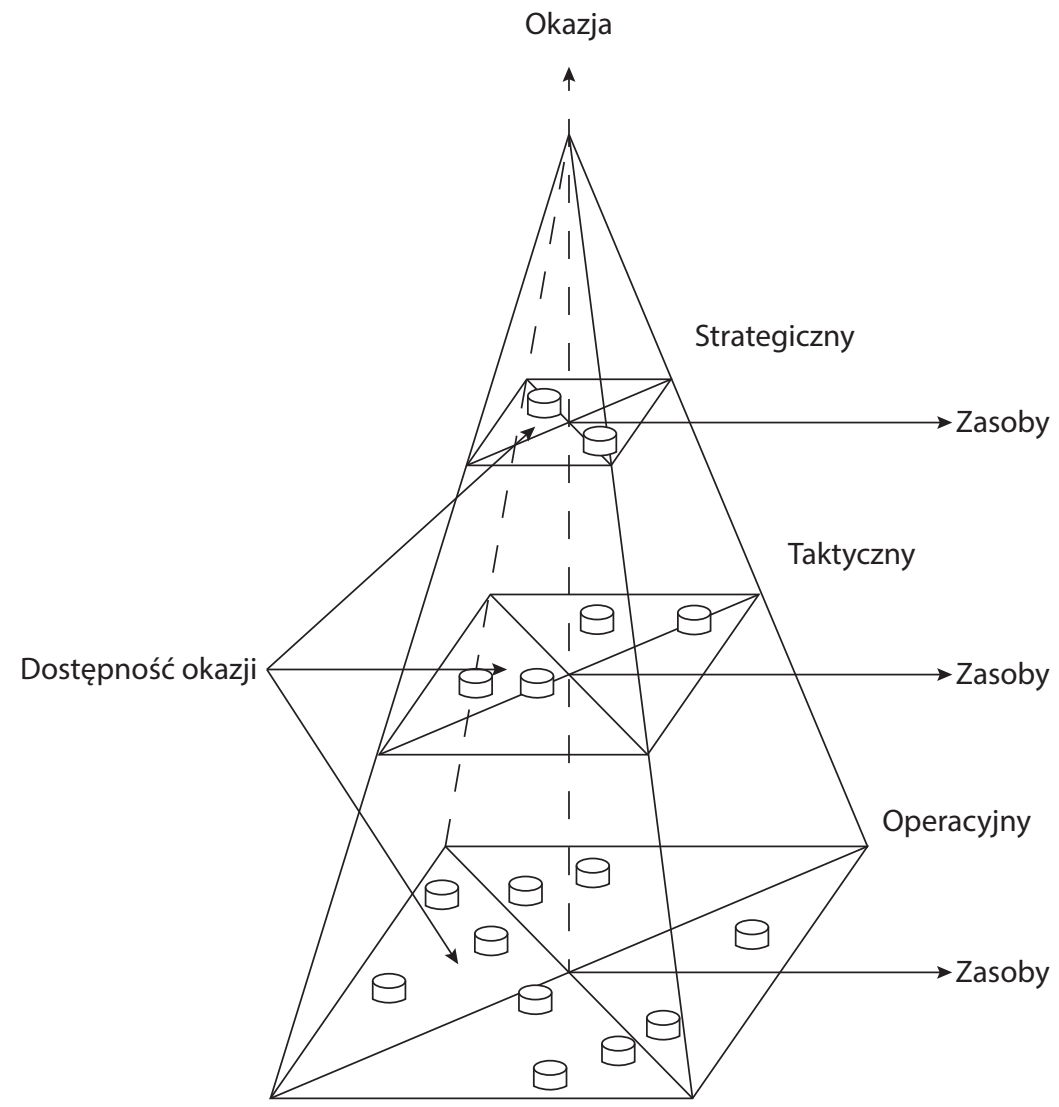

Rysunek 4. Charakter okazji a dostępność zasobów

Źródto: opracowanie własne na podstawie P. Królas, H. Włodarkiewicz-Klimek, Okazje - źródła, rodzaje i ryzyko, [w:] S. Trzcieliński, T. Zaborowski (red.), Kształtowanie zwinności przedsiębiorstw, Komitet Nauk Organizacji i Zarządzania Polskiej Akademii Nauk, Oddział w Poznaniu, Instytut Badań i Ekspertyz Naukowych, Gorzów Wielkopolski 2015, s. 94-105. 
Przedstawione podejście do identyfikacji okazji ze względu na jej charakter i dostępność zasobów ma charakter poglądowy. Stanowi punkt odniesienia do przeprowadzonych badań empirycznych, w których zostały zidentyfikowane i urzeczywistnione okazje.

\section{Studium przypadku}

Badania zostały przeprowadzone na grupie dziesięciu celowo wybranych przedsiębiorstw MSP, znajdujących się w trzech województwach. Wszystkie przedsiębiorstwa wymienione w tabeli 2 miały ugruntowaną pozycję na rynku świadczonych usług. W badanej grupie znalazły się firmy deweloperskie, usługowe, transportowe i produkcyjne (tabela 2).

Tabela 2. Wykaz działalności badanych przedsiębiorstw ${ }^{34}$

\begin{tabular}{|r|l|l|l|l|}
\hline Lp. & Przedsiębiorstwo & \multicolumn{1}{|c|}{ Branża } & \multicolumn{1}{|c|}{ Wielkość } & \multicolumn{1}{|c|}{ Województwo } \\
\hline 1 & Alpha & Deweloperstwo & Mikro & Wielkopolskie \\
\hline 2 & Beta & Deweloperstwo & Mikro & Pomorskie \\
\hline 3 & Gamma & Usługowa & Małe & Wielkopolskie \\
\hline 4 & Delta & Usługowa & Mate & Wielkopolskie \\
\hline 5 & Epsilon & Transportowa & Mate & Wielkopolskie \\
\hline 6 & Dzeta & Produkcyjna & Średnie & Wielkopolskie \\
\hline 7 & Eta & Produkcyjna & Średnie & Wielkopolskie \\
\hline 8 & Theta & Produkcyjna & Średnie & Małopolskie \\
\hline 9 & Jota & Produkcyjna & Średnie & Wielkopolskie \\
\hline 10 & Kappa & Produkcyjna & Średnie & Wielkopolskie \\
\hline
\end{tabular}

Źródło: opracowanie własne.

Podstawowym kluczem wyboru przedsiębiorstw było wdrożenie podejścia procesowego, w którym autor niniejszego opracowania brał udział jako konsultant i audytor. Studia przypadków prowadzone były przez cztery lata. W zależności od organizacji badanie trwało od trzech miesięcy do półtora roku. Badania w przedsiębiorstwach były prowadzone w sposób równoległy. Do podstawowych metod badawczych wykorzystanych w studium przypadku należy zaliczyć:

- obserwację bezpośrednią (obejmowała ona uczestnictwo autora we wdrożeniu podejścia procesowego, bazującego na systemach projakościowych);

- audyt organizacji w ujęciu możliwości implementacji podejścia procesowego w organizacji;

34 Autor publikacji nie otrzymał zgody na publikowanie niektórych nazw przedsiębiorstw przedstawionych w studium przypadku. Na potrzeby rozdziału firmy oznaczono literami alfabetu greckiego. 
- wywiad i konsultacje z kadrą kierowniczą przedsiębiorstwa, dotyczące opracowanego podejścia procesowego, w tym określenia możliwości wystąpienia okazji;

- analizę dokumentacji związanej z wykorzystaniem okazji.

Tabela 3. Urzeczywistnienie okazji na przykładzie wybranych przedsiębiorstw

\begin{tabular}{|c|c|c|c|c|}
\hline Lp. & Okazja & Warunki otoczenia & $\begin{array}{c}\text { Charakter } \\
\text { okazji }\end{array}$ & Uzyskane wyniki \\
\hline 1 & $\begin{array}{l}\text { Sprzedaż } \\
\text { udziałów }\end{array}$ & $\begin{array}{l}\text { - Brak terenów pod budowę } \\
\text { na Półwyspie Helskim } \\
\text { - Brak warunków zabudowy } \\
\text { - Ograniczone środki } \\
\text { dewelopera } \\
\text { - Cykl inwestycyjny }\end{array}$ & Strategiczny & $\begin{array}{l}\text { - Pozyskanie inwestora } \\
\text { - Uzyskanie warunków } \\
\text { zabudowy } \\
\text { - Uzyskanie } \\
\text { pozwolenia } \\
\text { na budowę } \\
\text { - Wybudowanie } \\
\text { mieszkań } \\
\text { - Sprzedaż mieszkań }\end{array}$ \\
\hline 2 & $\begin{array}{l}\text { Wykorzystanie } \\
\text { warunków } \\
\text { zabudowy }\end{array}$ & $\begin{array}{l}\text { - Zmiany w planach } \\
\text { zabudowy miasta (powyżej } \\
\text { 0,5 mln mieszkańców) } \\
\text { - Wykorzystanie warunków } \\
\text { zabudowy } \\
\text { - Ograniczone możliwości } \\
\text { zakupu nieruchomości } \\
\text { w centrum miasta } \\
\text { - Ograniczone środki } \\
\text { dewelopera }\end{array}$ & Strategiczny & $\begin{array}{l}\text { - Uzyskanie } \\
\text { pozwolenia } \\
\text { na budowę } \\
\text { - Uzyskanie kredytu } \\
\text { - Wybudowanie } \\
\text { mieszkań } \\
\text { - Sprzedaż mieszkań }\end{array}$ \\
\hline 3 & $\begin{array}{l}\text { Zamówienie } \\
\text { publiczne - firma } \\
\text { ustugowa }\end{array}$ & $\begin{array}{l}\text { - Duża konkurencja } \\
\text { - Brak wystarczających } \\
\text { zasobów własnych } \\
\text { - Konieczność } \\
\text { skonfigurowania } \\
\text { niezbędnych zasobów } \\
\text { - Złożenie oferty } \\
\end{array}$ & Operacyjny & - Wygrany przetarg \\
\hline 4 & $\begin{array}{l}\text { Uzyskanie } \\
\text { preferencyjnego } \\
\text { kredytu }\end{array}$ & $\begin{array}{l}\text { - Wysokie koszty pozyskania } \\
\text { kredytowania } \\
\text { - Wysokie odsetki: } 6-7 \% \\
\text { - Możliwość uzyskania } \\
\text { preferencyjnego } \\
\text { finansowania z WARPu } \\
-0,6 \%\end{array}$ & Taktyczny & $\begin{array}{l}\text { - Pozyskanie } \\
\text { finansowania }\end{array}$ \\
\hline 5 & $\begin{array}{l}\text { Dywersyfikacja } \\
\text { działalności }\end{array}$ & $\begin{array}{l}\text { - Mała konkurencja } \\
\text { (jeden punkt świadczący } \\
\text { podobne usługi) } \\
\text { - Poszerzenie działalności }\end{array}$ & Strategiczny & $\begin{array}{l}\text { Dywersyfikacja } \\
\text { działalności }\end{array}$ \\
\hline
\end{tabular}


Tabela 3 (cd.)

\begin{tabular}{|c|c|c|c|c|}
\hline Lp. & Okazja & Warunki otoczenia & $\begin{array}{c}\text { Charakter } \\
\text { okazji }\end{array}$ & Uzyskane wyniki \\
\hline 6 & $\begin{array}{l}\text { Zakup używanej } \\
\text { maszyny }\end{array}$ & $\begin{array}{l}\text { - Duża konkurencja na rynku } \\
\text { - Wysokie koszty zakupu } \\
\text { nowej maszyny }\end{array}$ & Taktyczny & $\begin{array}{l}\text { - Zakup używanej } \\
\text { maszyny }\end{array}$ \\
\hline 7 & $\begin{array}{l}\text { Akwizycja } \\
\text { przedsiębiorstwa } \\
\text { budowlanego }\end{array}$ & $\begin{array}{l}\text { - Poszerzenie zakresu usług } \\
\text { - Przejęcie zobowiązań } \\
\text { przejmowanego podmiotu } \\
\text { - Zwiększenie zakresu } \\
\text { oferowanych usług }\end{array}$ & Strategiczny & 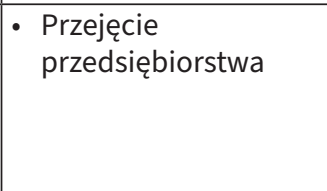 \\
\hline 8 & $\begin{array}{l}\text { Zakup } \\
\text { nieruchomości }\end{array}$ & $\begin{array}{l}\text { - Trudności w wyborze } \\
\text { lokalizacji } \\
\text { - Wysokie ceny } \\
\text { nieruchomości } \\
\text { - Konieczność } \\
\text { zabezpieczenia zasobów } \\
\text { przedsiębiorstwa }\end{array}$ & Strategiczny & $\begin{array}{l}\text { - Zakup nieruchomości } \\
\text { w strefie } \\
\text { ekonomicznej }\end{array}$ \\
\hline 9 & Projekt unijny & $\begin{array}{l}\text { - Spetnienie wymagań } \\
\text { formalnych (wielkość firmy } \\
\text { i przychód) } \\
\text { - Wytypowanie osób } \\
\text { biorących udziat } \\
\text { w projekcie }\end{array}$ & Operacyjny & $\begin{array}{l}\text { - Przystąpienie } \\
\text { do projektu unijnego }\end{array}$ \\
\hline 10 & $\begin{array}{l}\text { Zamówienie } \\
\text { publiczne } \\
\text { dla firmy } \\
\text { produkcyjnej }\end{array}$ & $\begin{array}{l}\text { - Wysokie wymagania } \\
\text { formalne } \\
\text { - Duża konkurencja } \\
\text { - Krótki termin na złożenie } \\
\text { dokumentów do przetargu }\end{array}$ & Operacyjny & - Wygranie przetargu \\
\hline
\end{tabular}

Źródło: opracowanie własne.

Na podstawie przeprowadzonych badań można stwierdzić, że dla mikrofirmy urzeczywistnienie okazji o charakterze strategicznym decyduje o sukcesie. W przypadku małych i średnich przedsiębiorstw (przypadki 5, 7, 8) wykorzystanie okazji o charakterze strategicznym prowadziło do uzyskania przewagi konkurencyjnej poprzez oferowanie nowych produktów, poszerzenia zakresu oferowanych usług czy też osiągnięcia korzyści z ulokowania organizacji w strefie ekonomicznej. Wykorzystanie okazji o charakterze taktycznym umożliwiło osiągnięcie celów przedsiębiorstwa przy racjonalnym gospodarowaniu środkami finansowymi. Z kolei wykorzystanie okazji o charakterze operacyjnym zapewniło podniesienie kompetencji pracowników, jak również pozyskanie nowego klienta. 


\section{Podsumowanie}

Istotą zwinności jest wykorzystywanie okazji pojawiających się w turbulentnym otoczeniu przedsiębiorstwa. Do głównych atrybutów zwinność należy zaliczyć: szybkość, elastyczność, zdolność do rekonfigurowania zasobów w celu zaspokojenia potrzeb klienta.

Okazja to sytuacja sprzyjająca podmiotowi decyzyjnemu, która może, ale nie musi być wykorzystana. Jej urzeczywistnienie zależy od szybkości reakcji na zdarzenia występujące w otoczeniu przedsiębiorstwa, możliwości skonfigurowania niezbędnych zasobów (własnych lub cudzych), a także od samego celu ${ }^{35}$. Okazje można podzielić ze względu na poziom subiektywności, przestrzeń okazji i charakter okazji.

Na podstawie przeprowadzonych badań można stwierdzić, że urzeczywistnienie okazji decyduje o powodzeniu przedsiębiorstwa. Dotyczy to zarówno mikro-, małych, jak i średnich przedsiębiorstw.

Wykorzystanie okazji w każdej z przedstawionych organizacji zapewniło jej sukces. Nie należy jednak traktować przedstawionych przypadków w kategorii stricte przedsiębiorstwa zwinnego, a jedynie zwinnych zachowań organizacji, które umożliwiły odniesienie korzyści. Jest to związane z wykorzystaniem pojedynczej okazji, która została zdiagnozowana w otoczeniu przedsiębiorstwa.

\section{Bibliografia}

Aghina W., De Smet A., Weerda K., Agility: It rhymes with stability, „McKinsey Quarterly”, December 2015, s. 1-12.

Alvarez S.A., Barney J.B., Discovery and Creation: Alternative Theories of Entrepreneurial Action, „Strategic Entrepreneurship Journal” 2007, vol. 1, no. 1-2, s. 11-26.

Ansof I., Zarzqdzanie strategiczne, Państwowe Wydawnictwo Ekonomiczne, Warszawa 1985.

Ardichvili A., Cardozo R., Ray S., A theory of entrepreneurial opportunity identification and development, „Journal of Business Venturing” 2003, no. 18, s. 105-123.

Banaszak P., Zwinne dostosowanie przedsiębiorstw na rynkach z okazjonalna przewaga konkurencyjnq, „Ruch Prawniczy, Ekonomiczny i Socjologiczny” 2014, z. 1, s. 185-210.

Brosseau D., Ebrahim S., Handscomb C., Thaker S., The journey to an agile organization, „McKinsey Quarterly", May 2019, s. 1-10.

Casson M., The entrepreneur: An economic theory, Barnes \& Noble Books, Totowa 1982.

Doz Y.L., Kosonen M., Fast strategy. How strategic agility will help you stay ahead of the game, Wharton School Publishing, London 2008.

Drucker P.F., Myśli przewodnie Druckera, Wydawnictwo MT Biznes, Warszawa 2001.

Dubisz S. (red.), Uniwersalny słownik języka polskiego, Wydawnictwo Naukowe PWN, Warszawa 2006.

35 S. Trzcieliński, Zwinne... 
Eckhardt J., Shane S., Opportunities and entrepreneurship, „Journal of Management” 2003, vol. 29, s. 333-349.

Goldman S., Nagel R., Preiss K., Agile competitors and virtual organization. Strategies for enriching the customer, Van Nostrand Reinhold, New York 1995.

Green J., The Opportunity Analysis Canvas. A New Tool for Identifying and Analyzing Entrepreneurial Ideas, Venture Artisans, LLC, Upper Marlboro 2015.

Grudzewski W.M., Hejduk I.K., Sankowska A., Wańtuchowicz M., Sustainability w biznesie. Przedsiębiorstwo przyszłości, Wydawnictwo Poltext, Warszawa 2010.

Gunasekaran A., Agile manufacturing: A framework for research and development, „International Journal of Production Economics" 1999, vol. 62(1-2), s. 87-106.

Hang C., Garnsey E., Ruan Y., Opportunity Discovery and Creation in Disruptive Innovation, Centre for Technology Management Working Paper Series, Institute for Manufacturing, at the University of Cambridge, Engineering Department, no. 03, Cambridge 2003.

Holbeche L., The agile organization, Kogan Page, London 2015.

Hunter M., Typologies and sources of entrepreneurial opportunity, „Economics, Management, and Financial Markets" 2013, vol. 8(3), s. 55-100.

Kałkowska J., Pawłowski E., Trzcielińska J., Trzcieliński S., Włodarkiewicz-Klimek H., Zarządzanie strategiczne. Metody analizy strategicznej z przykładami, Wydawnictwo Politechniki Poznańskiej, Poznań 2010.

Karpacz J., Determinanty dostrzegania i wykorzystania okazji przez przedsiębiorców, [w:] A. Stabryła (red.), Koncepcja zarzq̨dzania wspótczesnym przedsiębiorstwem, seria „Encyklopedia Zarządzania", Mfiles.pl, Kraków 2010, s. 45-52.

Koen P., Ajamian G., Burkart R., Clamen A., Davidson J., D’Amore R., Elkins C., Herald K., Incorvia M., Johnson A., Karol R., Seibert R., Slavejkov A., Wagner K., Providing clarity and a common language to the fuzzy front end, „Research Technology Management” 2001, vol. 44, s. 46-55.

Królas P., Identyfikacja ryzyka zwiqzzanego z krótkim cyklem życia okazji - studium przypadku, „Zeszyty Naukowe Politechniki Poznańskiej. Organizacja i Zarządzanie” 2019, z. 80, s. 149-163.

Królas P., Włodarkiewicz-Klimek H., Okazje - źródła, rodzaje i ryzyko, [w:] S. Trzcieliński, T. Zaborowski (red.), Ksztattowanie zwinności przedsiębiorstw, Komitet Nauk Organizacji i Zarządzania Polskiej Akademii Nauk, Oddział w Poznaniu, Instytut Badań i Ekspertyz Naukowych, Gorzów Wielkopolski 2015, s. 94-105.

Krupski R. (red.), Elastyczność organizacji, Wydawnictwo Uniwersytetu Ekonomicznego we Wrocławiu, Wroctaw 2008.

Krupski R. (red.), Zarzq̨dzanie przedsiębiorstwem w turbulentnym otoczeniu, Polskie Wydawnictwo Ekonomiczne, Warszawa 2005.

Lu Y., Ramamurthy K., Understanding the link between information technology capability and organizational agility: an empirical examination, „MIS Quarterly” 2011, vol. 35(4), s. 931-954.

Olajiga F., Lean agile marketing. How to become agile and deliver marketing success, Conversion Ltd., Northampton 2017.

Peiris I., Akoorie M., Sinha P., Conceptualizing the Process of Opportunity Identification in International Entrepreneurship Research, „South Asian Journal of Management”, July - September 2013, vol. 20, issue 3, s. 49-50.

Rothman J., Agile and Lean, Practical Ink, Arlington 2016.

Sajdak M., Zwinność strategiczna przedsiębiorstw, Wydawnictwo Uniwersytetu Ekonomicznego w Poznaniu, Poznań 2019.

Shane S., Prior Knowledge and the Discovery of Entrepreneurial Opportunities, „Organization Science" 2000, vol. 11, s. 448-469. 
Skat-Rørdam P., Zmiany decyzji strategicznych. Wykorzystanie okazji rynkowych do rozwoju przedsiębiorstwa, Wydawnictwo Naukowe PWN, Warszawa 2001.

Sull D., The upside of turbulence. Seizing opportunity in an uncertain world, Harper Collins Publishers, New York 2009.

Thomson A., Strickland A., Strategic Management. Concepts and Cases, Irwin, Burr Ridge 1993.

Timmons J., Spinelli S., New ventures creation, McGraw-Hill Companies, Inc., New York 1990.

Trzcieliński S., Zwinne przedsiębiorstwo, Wydawnictwo Politechniki Poznańskiej, Poznań 2011.

Włodarkiewicz-Klimek H., Kapitał ludzki w ksztattowaniu zwinności przedsiębiorstw opartych na wiedzy, Wydawnictwo Politechnik Poznańskiej, Poznań 2018.

Yusuf Y.Y., Sarhadi M., Gunasekaran A., Agile manufacturing: the drivers, concepts and attributes, „International Journal of Production Economics” 1999, vol. 62(1-2), s. 33-43.

\section{Streszczenie}

Otoczenie organizacji kreuje szanse i zagrożenia dla przedsiębiorstwa. Przedsiębiorstwa identyfikują możliwość odniesienia korzyści w sposób celowy lub niezamierzony. Jednym ze sposobów odniesienia korzyści w otoczeniu przedsiębiorstwa jest wykorzystanie okazji. Okazja jest rozumiana jako sytuacja sprzyjająca podmiotowi działania. Umiejętność jej uchwycenia i wykorzystania jest domeną przedsiębiorstw zwinnych.

W opracowaniu przedstawiono ujęcie teoretyczne i praktyczne zagadnienia. W części teoretycznej omówiono zagadnienia przedsiębiorstwa zwinnego i okazji. W części empirycznej przedstawiono wyniki badań, w ramach których zostały ukazane zwinne zachowania organizacji, które doprowadziły do wykorzystania okazji.

Słowa kluczowe: okazja, przedsiębiorstwo zwinne

Opportunity as an indicator of an agile enterprise - case study

\section{Abstract}

The environment of the organization creates opportunities and threats for the enterprise. Enterprises identify the possibility of benefiting either intentionally or unintentionally. One way to benefit in the business environment is to seize the opportunity. An opportunity is understood as a situation conducive to the subject of action. The domain of agile enterprises is the ability to capture and use of the opportunity.

The article presents the theoretical and practical issues. The theoretical part discusses the issue of agile enterprise and opportunity. The empirical part presents the results of research, which showed the agile behavior of the organization that led to the use of opportunities.

Keywords: agile enterprise, opportunity 